\title{
CRACKING FOUNDATIONS AS FEMINIST METHOD
}

\author{
KATHARINE T. BARTLETT*
}

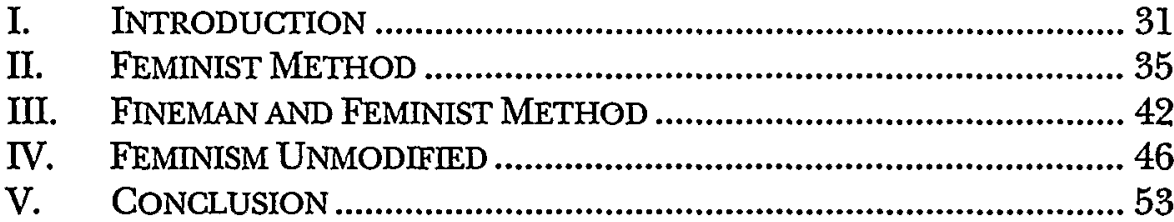

\section{INTRODUCTION}

Two facts: one, Martha Fineman is a feminist; and two, in this lecture and in her other work, she makes a case for greater public responsibility for society's caretakers and their dependents. Is there a connection?

In this essay I use Fineman's lecture on dependency as an excuse to explore what makes a scholar, or her work, "feminist." Many scholars have attempted to define "feminist" in relation to law, particularly as it is used in the terms "feminist" legal theory and "feminist" jurisprudence. All agree that the term refers in some way to the subject matter of women. ${ }^{1}$ Few claim, however, that anything having to do with women is, on that account, feminist. ${ }^{2}$ Most understand feminism to mean something more. But what more, exactly? And is it a matter of method or substance? As method, feminism refers to the nature of the questions asked, the criteria of relevance and proof applied in addressing those questions, and other methodological

* A. Kenneth Pye Professor of Law, Duke University School of Law.

1. Some commentators have pointed out, however, that feminism needs to be concerned about the way men, as well as women, are constructed. See, e.g., NANCY LEVTT, THE GENDER LINE, MEN, WOMEN, AND THE LAW (1998).

2. Some definitions stop at this point. See Larry Alexander, What We Do, and Why We Do It, 45 STAN. L. REV. 1885, 1889 (1993) ("I will define feminist jurisprudence to include all scholarship that focuses on the legal system's impact on women and women's impact on the legal system. ${ }^{n}$ ). 
issues. If feminism is viewed in terms of method, Fineman is a feminist so long as she asks the right kinds of questions and otherwise respects the appropriate protocols and standards of proof in trying to answer these questions. The label would say nothing, however, about the content of her substantive analysis, or the correctness of her conclusions from a prescribed feminist viewpoint.

As substance, feminism refers to the answers feminists get. If whether an analysis is feminist is judged in substantive terms, it is evaluated according to the content of the conclusions, rather than the method by which they were reached. Within this view, Fineman's analysis of dependency and the proposals that follow are feminist only if they conform to whatever substantive criteria are attached to the term.

Given how often critiques or reforms are said to be feminist, there is surprising ambiguity as to whether this refers to saying the right (feminist) things, or to arriving at conclusions in the right (feminist) way, or some other combination of these or other possibilities. ${ }^{3}$ In defining feminist legal scholarship, feminist scholars often emphasize its methodological aspects. ${ }^{4}$ To the extent feminists recognize the validity of disagreement on substantive positions within feminism, as they frequently $\mathrm{do},{ }^{5}$ they also seem to be presupposing a methodological over a substantive definition of the term.

Viewing feminism as just method in the sense of mere process,

3. Among other possibilities, for example, proposals could be considered feminist if they are made by anyone who claims to be a feminist, or if they simply purport to advance women's interests. See Gary Lawson, Feminist Legal Theories, 18 HARV. J.L. \& PUB. POL'Y 325 (1995) (discussing the dangers of defining certain ideas or sets of ideas as "feminist legal theory"). In this essay, I stick to the method and substance explanations, both because they are the two most significant and plausible possibilities, and because my real purpose is to explore the relationship between the two.

4. See generally Jeanne L. Schroeder, Abduction From the Seraglio: Feminist Methodologies and the Logic of Imagination, 70 TEx. L. REv. 109 (1991); Katharine T. Bartlett, Feminist Legal Methods, 103 HARV. L. REV. 829 (1990); CATHARINE A. MACKInNON, TOWARD A FEMINIST THEORY OF THE STATE 106-25 (1989); Christine A. Littleton, Feminist Jurisprudence: The Difference Method Makes, 41 STAN. L. REV. 751 (1989) (Book Review).

5. See generally alison M. Jaggar, Feminist Politics and Human Nature (1983) (distinguishing liberal feminism, Marxist feminism, radical feminism, and socialist feminism, in accordance with the different accounts of human nature, political values, and epistemological assumptions underlying each type); MARTHA CHAMALLAS, INTRODUCTION TO FEMINIST LEGAL THEORY 31-112 (1999) (distinguishing feminist theories associated with the "equality stage," the "difference stage," and the "diversity stage" (including "postmodern feminist") of feminist legal thought); Katharine T. Bartlett, Gender Law, 1 DUKE J. GENDER L. \& POL'Y 1 (1994) (distinguishing formal equality, substantive equality, nonsubordination theory, different voice theory, and postmodern feminism as different frameworks of feminist analysis); Carrie MenkelMeadow, Mainstreaming Feminist Legal Theory, 23 PAC. L.J. 1493 (1992) (referring to differences between "equality" feminists and "difference" feminists, and between "cultural" feminists and "radical" feminists"). 
however, does not seem quite right. Feminism is a movement that professes the desirability of social change. Surely a movement committed to social change is not indifferent to the substance of that change. In fact, feminists do appear to share certain substantive commitments: equal pay, the end of sexual harassment in the workplace, protection for victims of domestic violence, a woman's right to choose an abortion, and equality in family life. Feminism's opponents certainly assume that feminism stands for something - often typecast in exaggerated, unappealing ways-and decline to identify as feminists because of what they claim that something to be. In light of these general understandings, how can it be seriously contended that feminism has no substantive content?

The meaning of method and substance in feminist thought is a larger topic than can be tackled in one short essay. I have addressed aspects of the two elsewhere ${ }^{6}$ and do not intend to repeat my previous observations. In this essay, my limited goal is to probe some aspects of feminist method, including its relation to the content of feminist analysis, using the work of Martha Fineman as a focus. Fineman makes a particularly good subject for an exploration of the relationship between feminist method and feminist substance. Her global reputation is, indisputably, that of a feminist legal scholar. Her Feminism and Legal Theory workshop, which she has run since 1984 from the various universities at which she has been located (the law schools at the University of Wisconsin, Columbia, and Cornell), has drawn together feminist scholars from all over the world to discuss specific, cutting-edge topics in feminist legal theory and practice. Fineman now holds the Dorothea S. Clarke Professor of Feminist Jurisprudence Chair at Cornell Law School-the first "feminist" chair to be endowed at an elite U.S. law school. She has been as prolific as any other feminist legal scholar, the author of numerous books and articles, and editor of several collections of essays. In her writing, Fineman does not hesitate to take clear stands and advocate specific, substantive positions. ${ }^{7}$ At the same time, she is difficult to pigeonhole

6. See generally Bartlett, supra note 4 (detailing feminist legal methods, and discussing the method-substance dichotomy and the status of truth claims feminist methods produce); Katharine T. Bartlett, Tradition, Change, and the Idea of Progress in Feminist Legal Thought, 1995 WIS. L. REV. 303 (discussing use of tradition and change in feminist method); Katharine T. Bartlett, Minow's Social-Relations Approach to Difference: Unanswering the Unasked, 17 L. \& SocIAL INQUIRY 437 (1992) (Book Review) (discussing the link between progressive legal methods and progressive programs); Katharine T. Bartlett, MacKinnon's Feminism: Power on Whose Terms?, 75 CAL. L. REv. 1559 (1987) (Book Review) [hereinafter Bartlett, MacKinnon's Feminism] (evaluating the method of Catharine Mackinnon).

7. See infra Part III. 
into a particular brand of feminism. Many feminists, including myself, have disagreed with her on some matters. Given all of these factors, her scholarship should tell us something about what makes a scholar's work feminist, or what, if anything, knowing that an individual is a feminist scholar tells us about her, or about feminism.

I conclude in this essay what others have concluded before me, which is that the adjective "feminist," when applied to legal scholarship, is best understood as a methodological description. Understanding feminism in methodological terms acknowledges the commonality in the questions feminists ask about women's situations, over and over, in different contexts. Asking these common questions has produced many overlapping and alternative analyses of how gender is constructed and how it operates in the law. Most of these analyses, regardless of their incompatibilities, have contributed to a deeper understanding of how law affects what gender means, or could mean, in this society. Together, these multiple understandings of gender arrangements, along with the habit of questioning these arrangements, have given feminism a greater edge and made it more productive than any single view of these arrangements could provide. The alternative of understanding feminism in substantive terms, in contrast, risks locking it into a fixed, uncorrectable view of the world.

But while the crux of the term feminist is method, there is a critical aspect of feminist method that is substantive in nature. Feminist method works from a hypothesis which, in its simplest terms, boils down to something like this: the circumstances of women are unjust in significant respects and ought to be improved. This working hypothesis is sometimes characterized as a judgment ${ }^{8}$ or a belief, ${ }^{9}$ which suggests something fixed or settled. It is best understood, however, as an essential part-albeit substantive and provisional-of feminist method.

In Part II of this essay, I describe more fully what I mean by

8. See Janet Radcliffe Richards, Feminism and Equality, 9 J. CONTEMP. LEGAL IsSUES 225, 225-26 (1998) (speaking of the "judgment" that "[a]ll feminists must, presumably, be united in thinking that women have been, and still are, wrongly treated [or thought about, or regarded, or valued], and that this should be remedied"). Richards argues that while feminists may agree as a general matter that women's situation is unsatisfactory and should be improved, there is nothing within feminism itself that would account for any particular set of substantive views about what should be changed, why, and how. Id.

9. See, e.g., Clare Dalton, Where We Stand: Observations on the Situation of Feminist Legal Thought, 3 BERKELEY WOMEN's L.J. 1, 1-2 (1987-88) ( $\left.{ }^{\text {[ }} \mathrm{t}\right] \mathrm{o}$ be a feminist today . . . is to believe that we belong to a society... in which women are and have been subordinated by and to men, and that life would be better, certainly for women, possibly for everybody, if that were not the case."). See also JAGGar, supra note 5 , at 5 (noting that feminism includes "all those who seek, no matter on what grounds, to end women's subordination"). 
feminist method, and its relationship to the substantive conclusions feminists reach. In Part III, I use Martha Fineman's work to illustrate the significance of feminist method and the advantages of viewing it as both distinct from substance, and related to it. ${ }^{10}$ I further explore this particular methodological understanding of the term feminist by comparing it in Part IV to the method of Catharine MacKinnon. MacKinnon's method merges and becomes virtually indistinct from her substantive theory. In her skilled hands, this method-as-substance view has generated tremendous insights, perhaps made more easily understood by the uncompromising, unqualified nature of her claims. I argue, however, that as a general matter, her view is a less promising model for most feminist scholars than the model that can be derived from Fineman's work.

\section{FEMINIST METHOD}

Elsewhere I have explored three methods that feminists bring to legal analysis-asking the woman question, feminist practical reasoning, and consciousness raising. ${ }^{11}$ Together, these methods comprise an enterprise of looking for bias in the way the law relates to women, and proposing changes to eliminate that bias. As a result of engaging in this enterprise, feminists have generated significant new insights and analyses.

Feminist method was first applied by women suffragists when they challenged the self-rule premises of an all-male political system, a system that kept women from serving on juries, working in certain professions, becoming educated, owning property if they married, having custody of their children in the event of divorce, and controlling their own physical and sexual lives. ${ }^{12}$ These restraints had been rationalized on the grounds that women were different from men, that women needed special protection, and that the role assigned to them by God and nature was domestic and did not befit them for participation in government, commerce, or higher

10. I both criticize and defend the method/substance distinction in Bartlett, supra note 4, at $843-47$ (addressing the charge that the woman question is a mask for legal substance or politics).

11. See Bartlett, supra note 4 , at 831 .

12. See Declaration of Sentiments, Seneca Falls Convention, Seneca Falls, New York (July 1848), in HISTORY OF WOMEN'S SUFFRAGE, VOL. I, 1848-1861, at 70-71 (Elizabeth Cady Stanton, Susan B. Anthony \& Matilda Joslyn Gage eds., reprint ed. 1985) (1881-1922); Elizabeth Cady Stanton, Address to the Legislature of the State of New York (February 14, 1854), in id., at 595605; United States v. Anthony (1873), in HISTORY OF WOMEN's SUFFRAGE, VOL. II, 1861-1876, at 688-89. These documents can all be found in KATHARINE T. BARTLETT \& ANGELA P. HARRIS, GENDER AND LAW: THEORY, DOCTRINE, COMMENTARY 55-65 (2d ed. 1998). 
education. ${ }^{13}$ Some suffragists insisted on women's fundamental similarity to men, which made it unjust that they be treated differently. Others stressed their differences, and argued that women's participation in politics would balance male excesses and make for better government. ${ }^{14}$ Some argued both. ${ }^{15}$ Despite differences in analysis, nineteenth-century suffragists agreed on the unacceptability of a system that claimed to rest on principles of selfgovernment and yet excluded women.

Feminist litigators in the early 1970s also used feminist method when they challenged laws that explicitly treated women differently from men. These laws were based on stereotyped assumptions about women, including that they were less business-minded than men, ${ }^{16}$ dependent on their husbands, ${ }^{17}$ more likely to marry early and less likely to acquire higher education than their male counterparts, ${ }^{18}$ and less likely to drink and drive. ${ }^{19}$ Litigators challenged these assumptions, showing that although they were true about some men and some women, they were not true about all, and that even to the extent these assumptions were accurate, laws based upon them helped to create the reality they assumed. Because of the damage sex-based laws caused, especially to women, these litigators sought to eliminate them altogether and to require that all rules and practices treat women and men the same.

In the 1980s, some feminists used feminist method still again to probe more deeply into rules and practices, including gender-neutral

13. See, e.g., Bradwell v. Illinois, 83 U.S. 130 (1872) (mem.); Muller v. Oregon, 208 U.S. 412 (1908); West Coast Hotel Co. v. Parrish, 300 U.S. 379 (1937); Goesaert v. Cleary, 335 U.S. 464 (1948); Hoyt v. Florida, 368 U.S. 57 (1961).

14. See William Chafe, The AMERICAN WOMAN: Her Changing Social, ECONOMIC, AND POLITICAL ROLES, 1920-1970, at 13 (1972).

15. See, e.g., Elizabeth Cady Stanton, Address to the Legislature of the State of New York, February 14, 1854, in HISTORY OF WOMEN's SUFFRAGE, VOL. I, 1848-61, supra note 12, at 595-605.

16. See Reed v. Reed, 404 U.S. 71 (1971) (challenging a provision in the Idaho probate code that preferred males to females in selecting between people of equal entitlement to administer an estate).

17. See, e.g., Frontiero v. Richardson, 411 U.S. 677 (1973) (challenging a statute that allowed men to claim their wives as dependents regardless of actual dependency, while requiring women to prove actual dependence in order to claim their husbands); Weinberger v. Wiesenfeld, 420 U.S. 636 (1975) (challenging a statute that provided survivors' benefits only to women upon the death of their spouses); Orr v. Orr, 440 U.S. 268 (1979) (challenging an Alabama statute providing that husbands, but not wives, may be required to pay alimony upon divorce).

18. See Stanton v. Stanton, 421 U.S. 7 (1975) (challenging a Utah statute under which a female child was deemed to reach the age of majority at 18).

19. See Craig v. Boren, 429 U.S. 190 (1976) (challenging an Oklahoma statute that prohibited the sale of alcohol to males under 21 and females under 18). 
ones, to determine if, and how, they unjustly affected women. These feminists took women's disproportionate role in childbearing and childrearing as a given and argued that formal equality only masked that given. To obtain true equality with men, they argued, women required "special treatment" in such matters as hiring, pay, workplace accommodations, and public benefits, to counteract the disadvantages they experienced. ${ }^{20}$

Catharine MacKinnon ventured beyond both equal and special treatment solutions when she extended feminist method to question how laws, practices, and ways of thinking that are considered natural, objective and normal in fact reflect the interests of men. She concluded that male dominance and female subordination are achieved through specific definitions of male and female sexuality that pervade all aspects of the social, legal, political and economic order. MacKinnon did not oppose gains such as equal pay and equal access to employment that feminists had achieved under equality models, although she derided these gains as beneficial only to women who chose to be like men. ${ }^{21}$ Based on her analysis of the systemic and pervasive subordination of women, however, she argued that feminists needed to attend to the deeper, sexualized spheres of public and private life-pornography, sexual harassment, rape, among others-through which control over women's lives is both more invisible and insidious than in the case of explicit barriers to women's employment. Her analysis led her to favor restrictions on practices previously protected under the law, such as pornography and sexual harassment, and reform of legal standards, such as those that define rape, to better reflect women's experiences. ${ }^{22}$

Other feminists also asked the woman question when they inquired about the hidden value structure underlying the law (as well as the humanities, and the social, biological, and physical sciences), especially its emphasis on autonomy, individual rights, and privacy.

20. See, e.g., Linda J. Krieger \& Patricia N. Cooney, The Miller-Wohl Comtroversy: Equal Treatment, Positive Action, and the Meaning of Women's Equality, 13 GOLDEN GATE U. L. REv. 513 (1983). The "special treatment" terminology was soon dropped, but the feminist call for reform of the workplace to accommodate women with family responsibilities continued. See, e.g., Lucinda M. Finley, Transcending Equality Theory: A Way Out of the Maternity and the Workplace Debate, 86 Colum. L. REV. 1118 (1986); Kathryn Abrams, Gender Discrimination and the Transformation of Workplace Norms, 42 VAND. L. REV. 1183 (1989).

21. See Catharine A. MacKinnon, Feminism Unmodified: Discourses on Life and Law 37 (1987) ("The women that gender neutrality benefits, and there are some ... are mostly women who have been able to construct a biography that somewhat approximates the male norm, at least on paper. They are the qualified, the least of sex discrimination's victims. When they are denied a man's chance, it looks the most like sex bias.").

22. See generally MACKINNON, supra note 21; MACKINNON, supra note 4. 
These "different voice" feminists complained that a system based on "male" values degraded the alternative values of care, responsibility, and interdependency which women are more likely to hold. ${ }^{23}$ They argued that these alternative values would provide a better set of fundamental principles for society than "male" values of individual autonomy and a rights-based justice. ${ }^{24}$ Proposals for such reforms as a duty to rescue third-parties, ${ }^{25}$ a more progressive income tax structure, ${ }^{26}$ reforms in evidence law that demonstrate greater recognition of emotion and intuition, ${ }^{27}$ and workplace restructuring to accommodate the needs of working mothers ${ }^{28}$ were advanced by feminists pursuing such an analysis.

Feminists continued to apply feminist method to produce still different analyses and prescriptions for reform when in the 1990s they turned inward against feminism itself the questions and critiques that they previously had aimed at the legal status quo. Feminists questioned whether the movement's spokeswomen had confused their own perspectives with the perspective of all women; whether they had assumed as "natural" their own truths while the truths of others were dismissed as socially constructed "false consciousness;" whether they had elevated some presumed, common female experience of oppression over oppressions based on factors other than gender, such as race, class, and sexual orientation; and whether they had, in other ways as well, neglected to subject their own assumptions to the same scrutiny they had applied to others. ${ }^{29}$ These critiques challenged some of the most well-accepted truths among

23. See, e.g., Robin West, Jurisprudence and Gender, 55 U. CHI. L. REV. 1, 2-3 (1988) (asserting that all modern legal theory is masculine and that the legal concept of a "human being" contrasts with the construct of a "woman" in modern feminist theory).

24. See, e.g., Menkel-Meadow, supra note 5, at 1493; Leslie Bender, From Gender Difference to Feminist Solidarity: Using Carol Gilligan and an Ethic of Care in Law, 15 VT. L. REV. 1 (1990); West, supra note 23 , at $4-5$.

25. See Leslie Bender, A Lawyer's Primer on Feminist Theory and Tort, 38 J. LeGAL Educ. 3 (1988).

26. See Marjorie Kornhauser, The Rhetoric of the Anti-Progressive Income Tax Movement: A Typical Male Reaction, 86 MicH. L. Rev. 465, 510-13 (1987).

27. See Rosemary C. Hunter, Gender in Evidence: Masculine Norms vs. Feminist Reforms, 19 HARV. WOMEN'S L.J. 127, 131 (1996).

28. See Christine A. Littleton, Reconstructing Sexual Equality, 75 CAL. L. REV. 1279, 1279 (1987) (proposing an "acceptance" model of sexual equality which would reassess "the value society accords to traditionally "female' occupations," and revalue them "so as to render such value no less than that accorded to equivalent 'male' activities"); Finley, supra note 20, at 1119 . 20.

29. See Katharine T. Bartlett \& ANGela P. HaRris, Gender and LAW: Theory, DOCTRINE, COMMENTARY 1007-09 (2d ed. 1998) (reviewing various forms of feminist selfcritique, often referred to as anti-essentialist). 
feminists, including such matters as the desirability of limiting teenage pregnancy ${ }^{30}$ and the campaign against female genital surgeries. ${ }^{31}$

The different analyses that feminist method has produced, to which the quick summary above obviously does not begin to do justice, comprise a rich body of scholarship. This scholarship has evolved, however, in a context in which some have found the entire enterprise of feminist legal analysis to be illegitimate. Among the criticisms are that feminist scholarship is political, subjective, trivial, and lacking in methodological rigor. ${ }^{32}$ In considering the relationship between feminist method and substance, it is useful to consider some of this resistance.

Feminist scholarship is political, of course, in the sense that its primary interest is the way power is, and should be, distributed through rules, practices and institutions. This characteristic, however, does not distinguish feminist thought from political science, philosophy, sociology, international relations, or for that matter any other area of legal study that deals with the distribution of power. Given its solid company in the ranks of those who study political ideology, feminist legal analysis certainly cannot be viewed as objectionable on this count.

What about the concern, however, that feminist legal analysis focuses only on women's interests, rather than objective or neutral truths about human experience more generally? This charge appears to require a more serious response, one aided by an understanding of feminism as method. Method requires a hypothesis. The legal feminist's concern with women's interests is based on the hypothesis, which is based on prior findings or discoveries that the law, in different ways, disadvantages women. Feminist method looks for

30. See Regina Austin, Sapphire Bound!, 1989 WIS. L. REv. 539, 555 ("A black feminist jurisprudential analysis ... must seriously consider the possibility that young, single, sexually active, fertile, and nurturing black women are being viewed ominously because they have the temerity to attempt to break out of the rigid economic, social, and political categories that a racist, sexist, and class-stratified society would impose upon them.").

31. L. Amede Obiora, Bridges and Barricades: Rethinking Polemics and Intransigence in the Campaign Against Female Circumcision, 47 CASE W. RES. L. REv. 275, 311-18 (1997) (questioning outside interventions against female genital surgeries and the discounting by Western feminists of the perspectives of the African "victims"); Isabelle R. Gunning, Arrogant Perception, WorldTravelling, and Multicultural Feminism: The Case of Female Genital Surgeries, 23 CoLUM. HUM. RTS. L. REV. 189, 198-202 (1991-1992) (challenging arrogance by Western feminists and stereotyping of victims of genital surgeries).

32. See, e.g., Kenneth Lasson, Feminism Awny: Excesses in the Pursuit of Rights and Trifles, $42 \mathrm{~J}$. LEGAL EDUC. 1, 1I-13 (1991); Arthur Austin, Evaluating Stonytelling as a Type of Nontraditional Scholarhip, 74 NEB. L. REV. 479, 480-88 (1995). 
gender bias, based on the hypothesis that gender bias exists.

It is important to note that the feminist hypothesis that the law is not as neutral and objective as it claims to be when it comes to women is just that-a hypothesis. As a hypothesis, that judgment only kicks off the method. There is no impact (political or otherwise) from feminist method until it is proved. If the hypothesis is proved, this means that gender bias does (or did) exist, in which case it is not the scholar who has proved it that is partisan, but the law itself. ${ }^{99}$

In proving their hypotheses about gender bias, feminists follow intellectual processes not unlike those by which it is ordinarily determined what the law is, and should be. As Jeanne Schroeder points out, while the questions feminists ask and the hypotheses they pose are distinctive, their methods of proving their hypotheses, by and large, are not. ${ }^{34}$ To be sure, feminists attempt to de-construct and alter the standards for evaluating such matters as what proof is adequate, what facts are relevant, and what arguments are persuasive. $^{35}$ For example, feminists have used narrative and statistical accounts of women's actual experiences with sexual violence and harassment in order to challenge the official, malecentered scripts upon which the traditional rules of rape, domestic violence, and workplace harassment have been based. These accounts have provided the basis for different rules, including rules of evidence, that better reflect women's experiences.

Still, although feminist method looks to women's experiences for its evidence, it must establish what it purports to show. Factual assertions need to be proven, even if feminist inquiry results in altering what constitutes proof. Material must be relevant, even if feminists, applying feminist method, succeed in redrawing the boundaries of relevance. Normative claims must be persuasive, even if what is deemed persuasive is changed by feminist questioning of underlying assumptions and paradigms.

In important respects, feminist method has had much in common with the methods of law and economics scholarship. Law and

33. See Bartlett, supra note 4, at 847 (feminist method "confronts the assumption of legal neutrality and has substantive consequences only if the law is not neutral").

34. See Janet Radcliffe Richards, Why Feminist Epistemology Isn't (and the Implications for Feminist Jurisprudence), 1 LEGAL THEORY 365 (1996); Schroeder, supra note 4, at 117-18 (asserting that "many of the supposed differences in feminist method from masculinist method may be overemphasized," and that modern feminist technique is similar to the methodologies developed by many 20 th Century philosophers of science).

35. For a discussion of how feminist method helps to question existing bounds of relevance and alter the boundary lines, see Bartlett, supra note 4, at 849-63. 
economics scholars begin with a hypothesis-that individuals act in self-interested, profit-maximizing ways and that the law can best serve its goals if it takes account of these motivations. This hypothesis, based on prior discoveries that individuals act in self-interested, profit-maximizing ways, directs the inquiry of law and economics scholars in specific legal contexts to determine how the law operates, and how it might be improved to enhance desirable and efficient behavior. And like feminist scholarship, the hypothesis has no effect, other than to give direction to the research, until some proposition is shown through evidence and argument that is persuasive to those whom the scholars would like to persuade.

Also like law and economics scholarship, feminist legal analysis may be considered political or illegitimate when the real problem is that the analysis is simply not persuasive. There are, of course, different reasons an analysis may be unpersuasive. Legal analysis may fail to persuade because it goes beyond the audience's ability to comprehend it. Additionally, it may challenge too much of what the audience holds dear or takes for granted to be understood and believed. This is especially likely if the kind of claim upon which an analysis depends is normative or theoretical in nature, rather than empirical or scientific in the traditional sense. Feminist analysis, since the days of the early suffrage movement and before, has often made claims that so upset a given way of viewing the world as to be indigestible. Ironically, when this is the case the problem is not that feminist method is too political but, rather, that its detractors are too political to accept the truth. ${ }^{36}$

A quite different reason why some feminist legal analysis is unpersuasive is that it is, simply, bad scholarship. Feminist legal argument, like law and economics argument and any type of other legal analysis, may be poorly done. It may not be supported by adequate evidence. It may fail to account for relevant facts. The legal argument may be illogical or irrational; for example, it may assume the law is biased simply because women lose cases, or because women's accounts are not always believed. Being poorly done, however, does not apply to feminist scholarship with any greater force

36. Scholars who accuse feminist method of being political often take great pains to say that they are in favor of women's equality - that women should have the right to vote, serve on juries, own property, get equal pay for equal work, and the like. See Richard A. Posner, Conservative Feminism, 1989 U. CHI. LEGAL. F. 191. This support for women's equality, within the liberal, equal rights, formal equality paradigm is not considered politics but, rather, sound legal reasoning based in principle and doctrine. It is only the more radical theory and proposed doctrine that draw the charge "political." The charge evidences confusion between whether a legal claim or argument is political, and whether it is sound. 
or frequency than it does to other modes of legal scholarship.

As it turns out, much of feminist legal analysis is convincing under conventional criteria. It is supported by relevant empirical evidence, identifies inconsistencies, argues with convincing analogies, recognizes policy considerations and other accepted forms of persuasion, and appeals to familiar norms of justice. Like any other good legal analysis, good feminist scholarship makes clear its assumptions. It makes more sense of a phenomenon than prior explanations have done. It accommodates new evidence and can be modified in the face of counter-evidence. In fact, much of feminist legal analysis has been so convincing that, although once vigorously opposed as political, special interest pleading, it is now considered the objective, neutral truth. ${ }^{37}$

To illustrate some of the above points and to suggest further ones, I now turn to an example of feminist method in the scholarship of Martha Fineman.

\section{FINEMAN AND FEMINIST METHOD}

Throughout her scholarship, Martha Fineman looks for and finds a link between the law's treatment of the family and the oppression of women. Her search for this link is based on the hypothesis that it exists. Finding evidence of its existence has produced substantive conclusions about its nature.

In her lecture, Fineman examines two broad, hidden assumptions in U.S. law and politics: one, that the family is a separate, autonomous institution; and two, that the individual is the relevant unit of analysis in "jurisprudential constructions of justice or liberty." ${ }^{98}$ These assumptions, she argues, are "myths" that help to rationalize a society in which the burden of care for dependents is allocated to families. ${ }^{39}$ Families are considered "private" centers of affection and altruism; women do the work done in families; and, the work done within families is uncompensated. ${ }^{40}$ In this way, the gendered myths of individual independence, autonomy and self sufficiency "allow us to privatize individual dependency and pretend

37. Examples include women's right to vote and hold certain jobs at equal pay with men, and to be free of domestic violence in their homes and sexual harassment in the workplace, although in these and other areas uncontested as a general matter, plenty of controversy remains as to particular applications.

38. Martha Albertson Fineman, Cracking the Foundational Myths: Interdependence, Automomy, and Self Sufficiency, 8 AM. U.J. GENDER, SOC. POL'X \& L. 13 (2000).

39. Id. at 16.

40. Id. at $14,19$. 
that it is not a public problem."

After identifying these myths, Fineman "cracks" them open by comparing them to myths about the public sphere. ${ }^{42}$ She points out, for example, that subsidies designed to support various public goods are hidden as "investments" or "incentives," while subsidies designed to recognize otherwise uncompensated caretaking work are stigmatized as unearned charity. ${ }^{43}$ Similarly, she observes that those who pursue paid employment are considered independent and selfsufficient, while those who accept the unpaid tasks of caretaking are deemed dependent and unable to support themselves. ${ }^{44}$ As she analyzes these various assumptions, she demonstrates how they rationalize the distribution of costs of caretaking to those who do the caretaking in the private sphere, i.e., women. ${ }^{45}$ She looks at women's actual experiences to discern the costs of these burdens to women. ${ }^{46}$ In this lecture and in her other work, she identifies not only the immediate, obvious costs, but also the deeper, less visible costsderivative dependency that endures through the period of caretaking and often beyond, stigma to the caretakers, and abuse of caretakers who are too economically dependent on others to escape it.

Fineman offers not only a critique of existing societal institutions and their assumptions but also a prescriptive vision. Throughout her work, Fineman consistently accepts responsibility for revealing a system better than the one she criticizes. While far from fully developed in this lecture, and repeating much of what other advocates for women and children have suggested-flexible work weeks, job sharing without penalty, paid family leave, and a guaranteed living wage-Fineman proposes substantive measures to correct the inadequacies she finds in existing society. Although she understands the need to sift the possibilities pragmatically, with a view toward what might actually be achievable, she also envisions the seemingly impossible-in this lecture, a world with a 100 percent inheritance tax, and a lottery system for distributing disparate social goods ${ }^{47}$ - to test what a system that took seriously its own stated
41. Id. at 14 .
42. Id. at 20.
43. Fineman, supra note 38 , at 23.
44. Fineman, supra note 38 , at $17-18$.
45. Fineman, supra note 38 , at 20-21.
46. Fineman writes about the centrality to her method of taking women's experience in MARTHA ALBERTSON FINEMAN, THE ILLUSION OF EQUALITY: THE RHETORIC AND REALITY OF DIVORCE REFORM 8 (1991).

47. Fineman, supra note 38 , at 27. 
assumptions, or hers, would look like.

Each part of this method is characteristic of Fineman's scholarship. In describing her own feminist method in other work, Fineman has emphasized its critical, "explicitly woman-focused perspective."48 She has stressed the importance of challenging the fundamental concepts, values and assumptions embedded in the status quo, and her method's reliance on the specific experiences of women's lives rather than on abstract ideals. ${ }^{49}$ She has acknowledged that feminism is "a political theory concerned with issues of power," and challenged the status quo by assessing the ways in which specific results and rules are measured. ${ }^{50}$ She has recognized that questions pursued with rigor and a dedication toward connecting truth to reality are critical to the legitimacy of feminist scholarship and thus to the effectiveness of its insights and the success of its politics.

Applying this method, Fineman has reached numerous substantive conclusions throughout her work. For example, she has argued for an "abdication of equality" as a principle guiding divorce law. She has asserted that women and children have suffered from equalitybased alimony, property distribution, child custody and child support rules that fail to recognize the disproportionate sacrifices women make on behalf of their families and their increased dependency on others as a result of those sacrifices. ${ }^{51}$ Fineman has also applied her feminist method to challenge the unspoken distinction between the deserving and the undeserving poor and similar myths concerning single parents. ${ }^{52}$ These distinctions, she concludes, have been used intentionally as a way of demonizing poor, welfare mothers whose families are not dependent upon a man, thus reinforcing the norm of the nuclear, husband-wife family. ${ }^{53}$

I agree with Fineman on many substantive matters, including her analysis of the need for greater public responsibility for the care of dependents. I disagree with her on other matters. For instance, I am not persuaded that the problems of women and children of divorce can be attributed to the misguided efforts of liberal feminists to achieve equality in divorce and custody law. It has been gender

\footnotetext{
48. FINEMAN, supra note 46 , at 8.

49. Fineman, supra note 46, at 11 .

50. FINEMAN, supra note 46 , at 10 .

51. FINEMAN, supra note 46, at 173-90.

52. Martha Albertson Fineman, The Neutered Mother, the Sexual Family and OTHER TWENTIETH CENTURY TRAGEDIES 115-117 (1995).

53. Id.
} 
neutrality, not numerical equality, that liberal feminists have sought in all allocations of financial resources and child custody, a goal they share in common with Fineman, whose own proposals for needsbased alimony and a primary caretaker presumption are, themselves, gender neutral. I disagree also with Fineman's assertion that the state should be indifferent to marriage. Ideally, the state should recognize the benefits of two-parent families to children, and pursue appropriate measures to support the institution still preferred by many couples, without undermining the ability of unmarried couples who choose to have families to do so. ${ }^{54}$

I set forth these differences to show how feminists can disagree over matters of substance even as they pursue similar methods. Like other feminist scholars, we are asking questions about how women are treated in this society and how that treatment might be made more just. We operate from the working hypothesis that women's interests are compromised, by both rules and practices that have no explicit reference to women, sex, or gender, as well as by those that do. However, asking the same questions does not necessarily mean getting the same answers. The same answers may be expected only if the evidence is clear and the criteria for evaluating that evidence undisputed. ${ }^{55}$ Sometimes this is the case, but often it is not.

Disagreements among feminists should not be surprising. Feminism addresses the entire matter of how persons are, and ought to be, treated on account of their gender. Whether women are badly treated raises complex factual issues, because such basic matters as the nature and cause of differences between men and women remain highly contested and unresolved. Feminist scholarship is, as Mary Anne Case writes, a "heavily normative area of the law," in a society where there is little agreement about what gender does, and should, mean. ${ }^{56}$

54. I set forth my views relating to both of these examples in Katharine T. Bartlett, Saving the Family from the Reformers, 31 U.C. DAVIS L. REV. 809 (1998).

55. For example, there is much overlap in our positions on child custody. Fineman advocates a primary caretaker presumption. See FINEMAN, supra note 46, at 180-85. As a CoReporter for the American Law Institute's Principles of Family Dissolution project, I favor a more nuanced rule that attempts to approximate at divorce the distribution of caretaking time achieved by the parents before the divorce. This approach amounts to a primary caretaker rule when there has been a clear primary caretaker, a joint custody rule when the distribution of caretaking time has been roughly equal, and everything in between in accordance with caretaking patterns during the marriage-an approach known as the "approximation standard." See Bartlett, supra note 54, at 849-53. The approximation standard was first developed in Elizabeth S. Scott, Pluralism, Parental Preferences, and Child Custody, 80 CAL. L. REv. 615 (1992).

56. Mary Anne Case, Of Richard Epstein and Other Radical Feminists, 18 HARV. J.L. \& PUB. POL'Y 369, 370 (1995). 
The lack of substantive agreement among those who pursue feminist methods is explained further by the fact that these methods are not complete and self-contained. Feminist legal methods necessarily combine with other traditional methods: deduction, induction and other forms of logic, use of examples (hypothetical or otherwise) to make analogies and distinctions, weighing of policy considerations, and exercise of judgment. ${ }^{57}$ Just as scholars can disagree on the outcome of traditional legal analysis, feminist scholars can be expected to reach different analyses when they apply those same methods, combined with their own unique ones.

Feminist method is not total also because, particularly with respect to the normative questions feminists ask, individuals may bring commitments or values other than that of improving justice for women that affect the validity of a substantive analysis. Feminism does not obliterate all other value systems one might have. ${ }^{58}$ A person can entertain the working hypothesis that women's situation is unsatisfactory and should be improved, but still be politically liberal or conservative, religiously Muslim or Christian, economically capitalist or socialist. Feminists of different cultural backgrounds, races, economic circumstances, and religions can be expected to reach different conclusions on many matters, even if they are asking similar questions and respecting similar rules of proof.

The version of feminist method that understands different substantive conclusions can be best understood by contrasting it to an alternative view of method. This view is represented in Catharine MacKinnon's "feminism unmodified."

\section{FEMINISM UNMODIFIED}

Just as feminist substance may function as method, feminist method may sometimes function as substance. As I read it, such is the case with the work of Catharine MacKinnon. MacKinnon's method incorporates the feminist method I have described thus farthe method of breaking down existing rules, practices and ways of thinking to determine that women's interests are subordinated, and how. But it is more. MacKinnon describes her method as the

57. See generally HAROLd BERMAN \& WILIAM GREINER, THE NATURE AND FUNCTIONS OF LAW (4th ed. 1980); EDWARD LEVI, AN INTRODUCTION TO LEGAL REASONING (1948); see also Schroeder, supra note 4 , at 112.

58. See Angela P. Harris, Race and Essentialism in Feminist Legal Theory, 42 STAN. L. REV, 581, 585 (criticizing the idea that a woman's experience can be described independently of characteristics such as race, class, or sexual orientation).

59. See generally MACKINNON, supra note 21. 
apprehension of the truth of women's common experience of oppression through "believing women's accounts of sexual use and abuse by men." What makes this method truly radical is the nature of the truth this method produces. For MacKinnon, the truth is a feminism "unmodified," ${ }^{\text {"1 }}$ without "pre-existing modifiers" such as liberalism or socialism, which "extracts the truth of women's commonalties out of the lie that all women are the same. ${ }^{.62} \mathrm{~A}$ feminism unmodified is a feminism that rejects "gender-neutral absolutes, such as difference and sexuality and speech and the state" that serve to attribute to women themselves the qualities of women that make them unequal-their "femininity and submission and silence and exclusion"-rather than to the system which constructs them to be that way.

It would be easy to explain the uniqueness of MacKinnon's work in terms of the comprehensive, shocking nature of her substantive analysis. The possibility that all women share an all-encompassing subordination to men. The novel insight that subordination occurs through a process of sexual objectification, in which male dominance and female submissiveness are eroticized, naturalized, normalized, and universalized, in order to secure male power and women's inequality. ${ }^{63}$ The certainty that male dominance is so "pervasive and tenacious" that it is "metaphysically nearly perfect," "[i] ts point of view" the standard for "point-of-viewlessness," objectivity, and universality. ${ }^{64}$ The outrage that "[i]ts force is exercised as consent, its authority as participation, its supremacy as the paradigm of order, its control as the definition of legitimacy." ${ }^{165}$

What is distinctive about MacKinnon's work, however, is not only the radical substantive claims it makes but also the inseparability between these claims and the method that supposedly produces them. MacKinnon, like other feminists including Fineman, believes that women's situation is unjust and that the injustice is hidden and maintained through social and legal arrangements that appear

60. MACKINNON, supra note 21, at 5 .

61. Catharine A. MacKinnon, Feminism, Marxism, Method, and the State: Toward Feminist Jurispredence, 8 SIGNS 635,640 (1983).

62. See id. at $639 \mathrm{n} .8$ (noting that feminist method is the search to "define and pursue women's interest as the fate of all women bound together").

63. Sce id. at 635 (stating that "[t]he man/woman difference and the dominance/ submission dynamic define each other").

64. Id. at 638-39.

65. Id. at 639 . 
neutral and objective but, in fact, mirror male privilege. ${ }^{66}$ But for Fineman, this belief is the hypothesis she sets out to prove, while for MacKinnon, this belief is method and message, all in one. Mackinnon's theory is not something to be proved; rather, it presupposes what it claims to prove, and is structured so that no set of facts, logically, could ever disprove it. ${ }^{67}$ Women's accounts are to be believed, if they support the "truth" that all women experience the oppression she claims, and to be used as proof of their assimilation into male patriarchy if they do not. ${ }^{68}$ Her method is, as one scholar puts it, "a specific chosen political theory" rather than a process of truth-seeking. ${ }^{69}$

Significantly, MacKinnon refuses to imagine or describe a world that does not have the defects she identifies in this one. In one classic defense, she complains that asking her for a positive vision of the future

requests a construction of a future in which the present does not exist, under existing conditions.... This magical approach to social change, which is methodologically liberal, lives entirely in the head, a head that is more determined by present reality than it is taking seriously, yet it is not sufficiently grounded in that reality to do anything about it.... As a strategy for social change ... the "let's pretend" strategy is idealist and elitist both. ${ }^{30}$

Jeanne Schroeder comments that this failure makes her theory not only untestable in theory, but also in practice. "MacKinnon's name for her theory is accurate: feminism unmodified. An unmodifiable."11

Mackinnon understands that she has wrapped method and substance into one, but she makes no apologies. Method and substance are one, insofar as method "determines what counts as evidence and defines what is taken as verification." ${ }^{, 2}$ Method

both produces and proceeds from substantive conclusions on questions like relevance (what questions count? what evidence supports answers?), structure (what is connected with what, and

66. See, e.g., Mackinnon, supra note 61 , at 645 (discussing how the state, partially through its laws, institutionalizes male power).

67. MacKinnon's thesis is, in other words, "nonfalsifiable." See Schroeder, supra note 4, at 197. Schroeder is quick to add that the fact that Mackinnon's theory is nonfalsifiable does not make it false. $I d$.

68. Schroeder, supra note 4, at 197.

69. Schroeder, supra note 4, at 192.

70. MACKINNON, supra note 21, at 219.

71. Schroeder, supra note 4, at 199.

72. Mackinnon, supra note 4 , at 106 . 
how?), and reliability (when is information worthy of belief?). On this level, no matter how open to the world a method is, it is always to some degree tautologous. ${ }^{73}$

MacKinnon is right, of course, that all method has substantive implications, and that all substance is grounded in its method of production. Clearly feminist method, as outlined above, not only generates feminist insight about women's situation but also is generated by those insights. Substantive analysis of some aspects of women's situation has generated further hypotheses, consistent with that analysis.

MacKinnon's merger of method and substance, however, shortcircuits essential parts of the method and confuses hypothesis formation with hypothesis proving. ${ }^{74}$ MacKinnon's belief that there is only one feminism offers her, and us, no other way than her way to think about pornography, heterosexual sex, sexual harassment, prostitution, and the other topics with which she deals. Her view is the feminist view. All women are oppressed "as such." "75 If women do not realize it, it is because they are so oppressed that they are not aware of the extent to which what they experience as pleasure, or freedom, has been constructed by those who oppress them. ${ }^{76}$ If women defend other competing values such as free speech, consent, autonomy, or the like, they are collaborators in male supremacy. ${ }^{7}$

73. Mackinnon, supra note 4 , at 106.

74. Specifically about this distinction in the context of MacKinnon's work, see Schroeder, supra note 4 , at 109.

75. Catharine A. MacKinnon, From Practice to Theory, or What is a White Woman Anyway?, 4 YALEJ.L. \& FEMINISM 13, 21 (1991).

76. See MACKINNON, supra note 4, at 138 ("Women ... embrace the standards of women's place ... as "our own" to varying degrees and in varying voices-as affirmation of identity and right to pleasure, in order to be loved and approved and paid, in order just to make it through another day. This, not inert passivity, is the meaning of being a victim."); MACKINNON, supra note 21, at 39 "Women value care because men have valued us according to the care we give them.... Women think in relational terms because our existence is defined in relation to men."); MACKINNON, supra note 4, at 217 ("Some women eroticize dominance and submission; it beats feeling forced.").

77. In some respects, Mackinnon is harder on those who claim to be feminist (those to whom she sometimes refers as "putative feminists"), especially those who do not accept her position on pornography, than she is on right-wing women or on gender agnostics. For example, she accuses women who have succeeded under the gains secured by formal equality of defending their own relatively high position among women by keeping other women powerless. "It keeps the value of the most exceptional women high to keep other women out and down and on their backs with their legs spread." See MACKINNON, supra note 21, at 137. She soundly rejects the affiliation of those who disagree with her on pornography as feminists. Id. "I ... really want you on our side. But, failing that, I want you to stop claiming that your liberalism, with its elitism, and your Freudianism, with its sexualized misogyny, has anything in common with feminism." Id. But she states that Phyllis Schlafly should have been appointed to a position in the Reagan administration. Id. at 30. Simultaneously, she dismisses with dripping sarcasm a radical feminist who challenged Mackinnon's analysis that all women are subordinate 
Others might characterize debates over the appropriate legal response to pornography or prostitution as disagreements among feminists; MacKinnon views these debates not as matters of good faith disagreement, but as contests between real feminists and fake ones. Thus, in the context of one dispute over whether speakers who favored the legalization of prostitution should be allowed to be heard at a law school conference, she is said to have stated, "I don't see this as a fight within feminism, but a fight between those who wish to end male supremacy and those who wish to do better under it." ${ }^{78}$

Some feminists who might otherwise be bothered by the merging of her methodological and substantive claims have been eager to dismiss this apparent analytical sloppiness as a matter of strategy or tactics. Christine Littleton, for example, re-characterizes MacKinnon's substantive claims as matters of method, explaining away direct evidence to the contrary by the suggestion that the methodological aspect of her work "is often obscured by her presentation." ${ }^{79}$ Frances Olsen also defends MacKinnon on tactical grounds, responding to the charge against MacKinnon that she engages in too much "grand theory," and in too "dogmatic" a way by arguing that these devices are "politically mobilizing as well as intellectually stimulating. ${ }^{.80}$ The absence of ambiguity and complexity, Olsen writes, helps people to break their habits of thought and recognize what might be obscure if a more complex picture were presented. ${ }^{81}$

It is quite possible, to be sure, that MacKinnon's theory is more powerful and more seductive than if it conceded various exceptions and counter-facts. And there is no doubt that the theory has sparked more insight about how to think about sex and the law than any other contemporary feminist legal theory. If overstatement of the theory helped us to better grasp that theory, it would be hard to regret the methodological choices Mackinnon has made.

At the same time, feminist legal thought would be a very weak body

to men by remarking "[a]nd I understood with new clarity what conservative women have been trying to tell us about feminists." Id. at 306 n.6. For other references to MacKinnon's disdain for other women claiming to be feminist, see Bartlett, MacKinnon's Feminism, supra note 6, at 1564 n.5. B9.

78. Tamar Lewin, Furor on Exhibit at Law School Splits Feminists, N.Y. TIMES, Nov. 13, 1992, at

79. See Christine A. Littleton, Feminist Jurisprudence: The Difference Method Makes, 41 STAN. L. REv. 751, 755 (1989) (Book Review).

80. Frances Olsen, Feminist Theory in Grand Style, 89 CoLUM. L. REv. 1147, 1173 (1989) (Book Review).

81. Id. at 1175-76. 
of analysis, considered legitimate among only a small circle of uncritical fellow travelers, if MacKinnon's method were to set the standard. Most feminists, alas, do not have the ability MacKinnon does to present effectively a whole new way of looking at the relationship between gender and law. Even with respect to Mackinnon, once the power of her rhetoric and the thrill of her spectacular analysis have worn off, difficulties with MacKinnon's overstatements, inconsistencies, and ideological determinism begin to set in. As many have shown, Mackinnon's ideals are too simple, too black-and-white, too lacking in nuance and in the complexity of women's circumstances to be fully credible. ${ }^{82}$

It has long been puzzling to me that neither Mackinnon nor Fineman-two of the most well-known and respected U.S. contemporary feminists-recognizes the other in her work. ${ }^{83}$ This is not because they are not engaged in fundamentally the same feminist enterprise: exposing how gender matters and how it hurts women, in the laws and habits in which it is so invisibly embedded. Neither is their lack of engagement attributable to the difference in the respective subject matters they address. Although Fineman focuses on the family, and Mackinnon on pornography, rape, sexual harassment and prostitution, and despite the substantive differences in the application of their analysis, ${ }^{84}$ their theories are strikingly parallel. To Fineman, the traditional family has been idealized, subsidized, (hetero-)sexualized, naturalized, and mischaracterized as "self-sufficient" and "independent," thereby harming women and their children. ${ }^{85}$ To Mackinnon, women have been harmed by men's definition of sex, which "enforces woman's definition,

82. See Kathryn Abrams, Ideology and Women's Choices, 24 GA. L. REv. 761, 761-62 (1990) (arguing that MacKinnon's ideological determinism, justified by some feminist scholars on strategic grounds, is not actually effective strategy, in that it distances women trying to make do with complex and painful choices and weakens the premise of women's rights battles that presuppose women's competence to choose for themselves); Bartlett, MacKinnon's Feminism, supra note 6, at 1563-65 (noting inconsistencies and failure of MacKinnon to address ambiguity and contradiction).

83. I find no references to Martha Fineman by Catharine MacKinnon, and one has to stretch to find any references to issues of family and dependency in Mackinnon's work. See MACKINNON, supra note 21, at 39 ("Women value care because men have valued us according to the care we give them, and we could probably use some."). The only reference to MacKinnon I find in Fineman's work is a critique of MacKinnon's attitude toward "abstract presentation." See FINEMAN, supra note 52 , at $42-43$.

84. For example, while it is apparent in this lecture and in her other work that Fineman accepts the mother-child relationship as a natural dyad, to be protected and supported instead of penalized by existing social arrangements, MacKinnon sees that relation as "a consequence of male supremacy, not its causal dynamic." Compare FINEMAN, supra note 52, with MACKINNON, supra note 21, at 53.

85. See FINEMAN, supra note 52, at 226-27. 
encircles her body, circumlocates her speech, and describes her life. ${ }^{86}$

More likely, their failure to engage is a result of differences in the way they view what they are doing as feminists. First, while MacKinnon purports to explain an all-encompassing, "metaphysically nearly perfect" system of male subordination of women, ${ }^{87}$ Fineman's method deliberately eschews the "meta-narrative" of "abstract grand theory presentations." Fineman favors, instead, "middle range" theory, that is focused on specific contexts of women's experiences and 'mediates between the material circumstances of women's lives and the grand theories of law."

In addition, MacKinnon and Fineman reflect quite different views of the relationship between their methods and their substantive analyses. For MacKinnon, if women apply the right methodfeminist method-they should get the same results-feminist results. ${ }^{89}$ Her confidence in her results, ironically, invokes the same objectivity and rationality that she criticizes in liberal legal thought. Fineman, though no less convinced than MacKinnon that her own substantive positions are correct, does not stake her feminism on the correctness of those positions. The commitment she holds as $a$ feminist is the commitment to dig deeper and deeper, correcting even her own positions if further questioning produces different answers. To some, her argument will be persuasive that caretaking work is both inevitable and absolutely necessary for society, and thus creates a collective societal debt to which each and every member of society is obligated. It will not be persuasive to others, but Fineman does not hide her substance in her method. She accepts the responsibility for proving her claims, and does not rely for their proof on the insistence that her arguments are the one true feminist way.

I do not mean to suggest that Fineman is a better scholar than MacKinnon, in the sense that more of what she claims is actually true. Fineman, like most of us, sometimes oversimplifies and overstates. The difference is that Fineman approaches the questions of feminism

86. MACKINNON, supra note 4, at 114.

87. MacKinnon, supra note 61 , at 638 .

88. FINEMAN, supra note 46 , at 7 .

89. This is not to say that Mackinnon would never change her mind. There are, in her work, occasional references to the possibility of revising her analysis. See, e.g., MacKinnon, Feminism, Marxism, Method, and the State: An Agenda for Theory, 7 SIGNS 515, 520 n.7 (1982) ("I aspire to include all women in the term 'women' in some way, without violating the particularity of any woman's experience. Whenever this fails, the statement is simply wrong and will have to be qualified or the aspiration (or the theory) abandoned."). 
as if the answers must still be found, whereas MacKinnon's questions beg her answers, and only her answers. For Fineman, answers different from hers may be wrong, but that does not make them nonfeminist, or anti-feminist, answers. Fineman finds difficult questions within feminism worth discussing. The purpose of one of the conferences in her Feminism and Legal Theory workshop, for example, was to explore and debate how feminism should address "bad" mothers. Presumably, Fineman would also be willing to discuss such matters as whether the woman who puts aside her career to raise her children-the woman for whom Fineman argues greater public support should be available-should be viewed as a "defector," who only makes things worse for other women in the workforce."

\section{CONCLUSION}

The value of recognizing multiple views within feminism might easily be dismissed as a misguided, "liberal" wishy-washiness that, in its lack of resolve and uncertain commitment, only benefits patriarchy. This dismissal, however, would ignore the gains to feminism of being a field of study, as opposed to a single point of view. Disciplines are formed not around a set of absolute truths but around a coalescence of agreement over the questions that are sufficiently important, and unresolved once and for all, to continue to be asked. If the substance is agreed to, the questions are no longer worth asking, and there is no need for a discipline to ask them. The history of sex discrimination as a field of study in law schools bears out this point in a small way. So long as there was only one "feminist" approach to the law-the formal equality approach-the study of sex discrimination was not a field of study in its own right, but only a single point of view, which could reasonably be tacked on to established courses, like family law, criminal law, and constitutional law. Only when alternative frameworks for thinking about the relationship between law and gender developed-a product, I would argue, of viewing the feminist enterprise in terms of method, not as a fixed set of substantive views-did the study of this relationship become understood as a course of study in its own right, capable of generating new analyses and ways of thinking.

Fineman ends her lecture with caution against "simplistic and hypocritical prescriptions" and "ideological placebos." This caution is directed primarily against the myths upon which the current status

90. This issue is raised in H.E. Baber, Tomboys, Femmes and Prisoner's Dilemmas, 9 J. CONTEMP. LEGAL ISSUES 37, 45-46 (1998). 
quo is founded. Cracking those myths is a central aspect of feminist method. One of the benefits of viewing what it means to do feminist scholarship in terms of method is that it reminds us that the method requires us to leave no myths untouched, not even our own. 